\title{
Program Pelatihan Menggosok Gigi Dalam Meningkatkan Keterampilan Bina Diri Siswa Tunagrahita di SLB se-Kota Padang
}

\author{
Safaruddin $^{1}$, Fatmawati ${ }^{2}$, Setia Budi ${ }^{3}$ \\ ${ }^{123}$ Universitas Negeri Padang, Indonesia \\ Email: safaruddin0366@fip.unp.ac.id
}

\section{INFORMASI ARTIKEI}

Terkirim 04 Oktober 2019

Revisi 16 Oktober 2019

Diterima 25 November 2019

\section{Kata kunci:}

Menggosok gigi, bina diri,

tunagrahita

\begin{abstract}
Education is a basic right that every child in general must have without exception. Academic, social and emotional abilities can develop well through education. The curriculum used in Indonesia at the moment was the 2013 curriculum. One of the schools that carries out educational activities was the Extraordinary School (SLB). SLB was one of the place whom expected to develop the development of mentally retarded children. Through Special School, mentally retarded children got academic and non-academic education that suits their needs. One of the skills that must be taught is the ability to brush your teeth. Retarded students in the moderate category still find it difficult to brushed parts of teeth that were located inside such as right and left teeth and inner teeth. In addition to the position of the teeth, the frequency and time of tooth brushing was also a problem for the mentally retarded child.
\end{abstract}

This is an open access article distributed under the Creative Commons Attribution ShareAlike 4.0 International, This license lets others remix, tweak, and build upon your work even for commercial purposes, as long as they credit you and license their new creations under the identical terms $\odot 2018$ by author.

\section{PENDAHULUAN}

Setiap sekolah baik dari sekolah umum (regular) maupun sekolah luar biasa (SLB) juga menerapkan sistem kurikulum 2013 tersebut. Setiap SLB memiliki program pendidikan yang bersifat akademik dan non akademik. Pendidikan akademik pada umumnya hampir sama dengan sekolah- sekolah regular. Namun, pada mata pelajaran tertentu harus disesuaikan dengan kebutuhan dan kemampuan anak sehingga anak dapat menerima informasi yang dijelaskan oleh guru. Sedangkan pada pendidikan non akademik lebih berfokus pada pengembangan program khusus. Berdasarkan Permen No. 22 tahun 2006 Program khusus berisi kegiatan yang bervariasi sesuai degan jenis ketunaannya, yaitu program orientasi dan mobilitas untuk peserta didik tunanetra, bina komunikasi persepsi bunyi dan irama untuk peserta didik tunarungu, bina diri untuk peserta didik tunagrahita, bina gerak untuk peserta didik tunadaksa, dan bina pribadi dan sosial untuk peserta didik tunalaras. Bina Diri mengacu pada suatu kegiatan yang bersifat pribadi, tetapi memiliki dampak dan berkaitan dengan human relationship. Disebut pribadi karena mengandung pengertian bahwa keterampilan-keterampilan yang diajarkan atau dilatihkan menyangkut kebutuhan individu yang harus dilakukan sendiri tanpa dibantu oleh orang lain bila kondisinya memungkinkan (Widya, 2003). Pembelajaran yang diberikan kepada anak tunagrahita sedang agar dapat melakukan kegiatan sehari-hari tanpa harus meminta bantuan kepada orang lain sehingga anak dapat mandiri (Ardiyanto, 2014).

SLB merupakan salah satu wadah yang diharapkan dapat mengembangkan bina diri anak tunagrahita. Hal itu mengharuskan SLB diwajibkan dapat memberikan kemampuan terbaik dalam menjalankan tugas dan kinerjanya. Salah satunya ditunjang dengan fasilitas dan sumber daya manusia (SDM yang sangat memadai. SLB memiliki berbagai macam jenis anak berkebutuan khusus, salat satunya anak tunagrahita. Tunagrahita merupakan kata lain dari Retardasi Mental (Mental Retardation) yang artinya terbelakang mental (Yosiani, 2014). Anak tunagrahita mengalami masalah dalam bina diri. Agar dapat menolong dirinya sendiri dalam menjalani kehidupan sehari-hari anak tunagrahita harus diberikan latihan bina diri sehingga anak tersebut tidak selalu tergantung dengan orang lain. Anak tunagrahita merupakan individu yang utuh dan unik, sama seperti anak pada umumnya memiliki hak sepenuhnya atas layanan pendidikan yang sesuai dengan kebutuhannya. kata tunagrahita merupakan asal dari kata tuna yang berarti 'merugi' sedangkan grahita yang berarti 'pikiran'. Meskipun anak tunagrahita memiiki hambatan pada intelektual, Namun anak tunagrahita ini juga masih memiliki potensi yang perlu dikembangkan sesuai dengan kapasitas yang dimiliki oleh anak tersebut.

Pendidikan yang mampu melayani anak tunagrahita adalah sekolah khusus yaitu Sekolah Luar Biasa. Melalui Sekolah Luar Biasa ini anak tunagrahita mendapatkan pendidikan yang bersifat akademik dan non akademik yang sesuai dengan kebutuhannya. Pendidikan yang bersifat akademik tidak jauh berbeda dengan sekolah-sekolah pada umumnya, namun ada beberapa yang dimodifikasi sesuai dengan kebutuhan anak. Sedangkan pendidikan non akademik khususnya bagi anak tunagrahita yaitu anak diajarkan pengembangan diri/ bina diri seperti menolong diri, merawat diri, dan kebersihan diri. 
Data World Health Organisation (WHO) tahun 2005 menunjukkan bahwa 90\% dari jumlah anak di dunia mengalami masalah kerusakan gigi. Hasil Riset Kesehatan Dasar (Riskesdas) 2007, karies gigi diderita oleh 72,1\% penduduk Indonesia dan dalam 12 bulan terakhir sebanyak 23,4\% penduduk Indonesia mengeluhkan adanya masalah pada gigi dan mulutnya (Sutjipto, Chrisdwianto., 2013). 91,1\% masyarakat Indonesia yang berumur di atas 10 tahun, meskipun sudah menggosok gigi setiap hari, namun hanya sebesar 7,3\% yang telah menggosok gigi secara benar, yaitu pagi setelah sarapan dan malam sebelum tidur. Sedangkan menurut penelitian yang dilakukan Unilever ditahun 2007, hanya terdapat 5,5\% masyarakat Indonesia yang memeriksakan kesehatan gigi secara teratur ke dokter gigi (Mostofsky, 2006; Pintauli, 2008).

Pembelajaran Bina Diri diajarkan atau dilatihkan pada ABK mengingat dua aspek yang melatar belakanginya. Latar belakang yang utama yaitu aspek kemandirian yang berkaitan dengan aspek kesehatan, dan latar belakang lainnya yaitu berkaitan dengan kematangan sosial budaya. Beberapa kegiatan rutin harian yang perlu diajarkan meliputi kegiatan atau keterampilan mandi, makan, menggosok gigi, dan ke kamar kecil (toilet); merupakan kegiatan yang sangat erat kaitannya dengan aspek kesehatan seseorang (Widya, 2003).

Anak tunagrahita mengalami masalah dalam bina diri. salah satunya dalam kegiatan merawat diri yaitu menggosok gigi. Menggosok gigi dapat dilakukan dua kali sehari dengan tujuan menyegarkan mulut dan gigi. Pada anak tunagrahita, permasalahan gigi yang paling sering ditemui yaitu karies gigi dan kelainan pada gusi (Pujiyasari, Hartini, \& Nurullita, 2014). Anak tunagrahita sangat membutuhkan pelatihan menggosok gigi dibandingkan dengan anak normal pada umumnya (Horner \& Keilitz, 2006). Salah satu penyebabnya yaitu dari fungsi gigi. Gigi bagi seorang anak penting dalam proses pertumbuhan dan perkembangan anak itu sendiri. Fungsi gigi sangat diperlukan dalam masa kanak-kanak yaitu sebagai alat pengunyah, membantu dalam berbicara, keseimbangan wajah, penunjang estetika wajah anak dan khususnya gigi sulung berguna sebagai panduan pertumbuhan gigi permanen (Pangemanan, 2014). Fungsi kognitif yang berada di bawah rata-rata juga dapat menyebabkan pelatihan pada anak tunagrahita harus dilaksanakan secara berulang-ulang dengan metode yang sangat sederhana dan menyenangkan. Kondisi pembelajaran pada anak tunagrahita di sekolah luar biasa seKota Padang mengalami permasalahan dalam memberikan latihan menggosok gigi. Anak tunagrahita sudah memiliki kemampuan dasar dalam menggosok gigi, tetapi belum secara optimal dan belum mencapai KKM yang ditetapkan. Hambatan yang dimiliki siswa yaitu belum memiliki pengetahuan tentang langkah-langkah menggosok gigi dengan benar.

Siswa tunagrahita kategori sedang masih merasa kesulitan dalam menggosok bagian-bagian gigi yang letaknya berada di dalam seperti gigi bagian kanan dan kiri serta gigi bagian dalam, siswa hanya mampu menggosok bagian tertentu saja seperti bagian depan dan bagian gigi graham atau gigi pengunyah. Hal ini dikarenakan belum adanya kegiatan rutin menggosok gigi di sekolah. Berdasarkan permasalah tersebut, maka upaya yang dapat dilakukan pada anak tunagrahita tersebut yaitu dengan cara memberikan program pelatihan bina diri.

Permasalahan yang dihadapi oleh mitra yaitu belum adanya kerjasama Sekolah Luar Biasa se-Kota Padang dengan dokter gigi sehingga kegiatan menggosok gigi hanya terbatas pada kegiatan bina diri. Selain itu, kemampuan anak tunagrahita yang berada di bawah rata-rata juga membuat kegiatan bina diri menjadi lebih sulit untuk dilakukan. Selain permasalahan dari sekolah, pandangan orang tua yang masih menganggap kurang pentingnya dalam menggosok gigi juga menjadi salah satu penghambat suksesnya anak mandiri dalam menggosok gigi.

\section{METODE}

Kegiatan yang dilakukan menggunakan beberapa metode dalam pelaksanaannya. Hal ini bertujuan agar hasil yang didapatkan dapat sesuai dengan sasaran yang menjadi tujuan akhir dari kegiatan ini. Beberapa metode yang digunakan adalah sebagai berikut:

1. Ceramah dan diskusi,

Setiap peserta pada pertemua pertama menerima materi menggunakan metode ceramah dan diskusi. Penyampaian materi yang diberikan kemudian akan dilanjutkan dengan diskusi. Setiap guru memberikan permasalahan peserta didiknya disekolah dan selanjutnya itu akan dibahas bersama. Materi yang akan diberikan kepada guru-guru mengenai:

1.1 Karakteristik Anak Berkebutuhan Khusus

Pada materi ini akan berfokus pada anak tunagrahita, hal ini bertujuan agar sasaran yang dicapai lebih terarah. Materi ini diharapkan dapat memberikan dasar-dasar yang berguna dalam kegiatan menggososok gigi pada anak tunagrahita

1.2 Pembelajaran menggosok gigi

Setiap sekolah diwajibkan membuat rancangan program pembelajaran. Ini bertujuan agar rancangan program pembelajaran yang dibuat akan lebih baik dari sebelumnya karena telah disesuaikan dengan karakteristik anak tunagrahita.

1.3 Program latihan menggosok gigi

Program latihan menggososk gigi digunakan untuk memantau kemampuan anak berdasarkan aspek-aspek dari prosedur menggosok gigi. Saat ini banyak anak yang tidak mau menggosok gigi dengan berbagai alasan. Selain itu beberapa anak mau menggosok gigi namun belum melakukannya dengan benar. Berdasarkan permasalahan tersebut, 
maka program latihan menggosok gigi ini sangat cocok untuk dibuat oleh guru sebagai pedoman dalam memberi latihan menggosok gigi pada anak tunagrahita

1.4 Praktek menggosok gigi

Kegiatan praktek menggosok gigi dilaksanakan setelah guru mendapatkan semua materi. Ini menjadi evaluasi berdasarkan materi yang telah diberikan sebelumnya.

2. Praktek mengajar siswa menggosok gigi

Pada bagian ini, setiap guru akan melakukan praktek mengajar siswa menggosok gigi yang akan diamati oleh dokter gigi.

2.1 Merancang program pembelajaran menggosok gigi

Program pembelajaran dirancang berdasarkan tema pelajaran yang ada pada kelas.

2.2 Praktek latihan menggosok gigi pada siswa tunagrahita

Praktek ini dilaksanakan oleh semua guru pada siswa tunagrahita dan diamati oleh dokter gigi.

\section{HASIL PENELITIAN DAN PEMBAHASAN}

Pelaksanaan kegiatan program pelatihan menggosok gigi dalam meningkatkan keterampilan bina diri siswa tunagrahita di SLB se-Kota Padang difokuskan pada kegiatan pelatihan mengenai menggosok gigi yang dilakukan oleh guru kepada peserta didiknya di sekolah masing-masing. Peserta yang hadir sebanyak 20 orang guru yang berasal dari 10 SLB yang ada di Kota Padang. Para peserta sangat antusias dalam mengikuti kegiatan pengabdian kepada masyarakat tersebut, dikarenakan memang permasalahan yang mereka alami di lapangan saat mengajar anak berkebutuhan khusus banyak terjawab saat pelaksanaan kegiatan. Hal ini dikarenakan kurangnya pemahaman guru dalam memberikan pembelajaran menggosok gigi pada anak tunagrahita di Sekolah. Berdasarkan hasil wawancara masih banyak anak tunagrahita yang jarang menggosok gigi di rumah. Sebagian kecil peserta didik lainnya mengatakan telah menggosok gigi sebelum pergi ke sekolah namun belum menggunakan teknik yang benar. Beberapa orang guru terkadang meminta peserta didik untuk mengulang menggosok gigi, namun mereka menolak permintaan tersebut dengan alasan telah melakukannya dirumah. Dalam kegiatan pengabdian kepada masyarakat ini melibatkan satu orang narasumber dari dosen pendidikan luar biasa dan tiga orang dosen dari fakultas kedokteran gigi.

1. Pencapaian Tujuan

Tujuan yang ingin dicapai pada kegiatan pengabdian ini adalah meningkatnya kompentensi guru dalam memahami karakteristik anak berkebutuhan khusus (anak tunagrahita) dan meningkatkan kemampuan guru dalam cara/teknik menggosok gigi sehingga dapat membantu anak tunagrahita dalam melatih binadiri anak tersebut. Pada saat kegiatan dilaksanakan, banyak guru menjelaskan bagaimana permasalahan-permasalahan yang dihadapi guru dalam mengajarkan anak menggosok gigi. Pada salah satu kasus, anak tunagrahita tersebuh masih bermasalah dalam memasukkan air ke dalam mulutnya. Setiap kali air dimasukkan ke dalam mulutnya, maka akan langsung ditelah oleh anak tersebut. Selain itu guru juga menjelaskan kerjasama sekolah dengan pihak kesehatan mengenai kegiatan menggosok gigi. Salah satu sekolah telah melakukan kegiatan menggosok gigi bersama dengan salah satu puskesmas. Sekolah lain melakukan kerjasama dengan pihak sekolah dengan durasi satu semester sekali kunjungan. Selebihnya, banyak sekolah yang belum melakukan kerjasama dengan pihak atau dinas kesehatan. Dalam teknik menggosok gigi, masih banyak terlihat guru menggunakan cara yang belum tepat dalam menggosok gigi. Hal ini dapat terlihat dari contoh yang diberikan oleh beberapa guru dalam menggosok gigi. Berdasarkan permasalahan tersebut, tim pengabdian kepada masyarakat melaksanakan kegiatan ini sehingga tujuan yang diinginkan dapat dicapai.

2. Pencapaian Target

Target dari pelaksanaan ini meliputi:

2.1 Memberikan pemahaman tentang karakteristik anak berkebutuhan khusus

Berdasarkan hasil kegiatan yang telah dilakukan, pemahaman guru mengenai anak berkebutuhan khusus sudah sangat baik. Pada materi ini lebih ditekankan pada karakteristik anak tunagrahita. Banyak anak-anak tunagrahita tidak mau menggosok gigi. Sehingga guru harus memberikan pendekatan-pendekatan yang berbeda dari biasanya. Selain itu, banyak juga anak-anak yang masih kesulitan dalam menggosok gigi sehingga guru harus mengajarkannya berulangulang.

2.2 Memberikan pemahaman tentang binadiri anak tunagrahita

Mata pelajaran binadiri di sekolah memiliki berbagai macam materi. Salah satunya menggosok gigi. Semua guru memiliki kemampuan dalam menggosok gigi, namun masih banyak yang masih mengalami kesulitan dalam 
kesempurnaan/ketepatan dalam melakukan kegiatan tersebut. Melalui materi yang diberikan diharapkan guru dapat memami materi binadiri bagi anak tunagrahita.

2.3 Memberikan pemahaman tentang RPP binadiri pada anak tunagrahita

RPP yang diberikan guru kepada anak tunagrahita harus menggunakan tematik. Pada materi ini guru diajarkan bagaimana sebuah mata pelajaran dapat bergabung dengan mata pelajaran lainnya tanpa mengurangi materi dari mata pelajaran yang lain tersebut. Hasil dari kegiatan ini terlihat bahwa semua sekolah/ perwakilan guru telah menyerahkan RPP yang telah dibuat dan dipraktekkan langsung ke materi tema yang ada.

2.4 Memberikan contoh praktek menggosok gigi dengan baik dan benar

Setelah memberikan metode materi malalui ceramah, kegiatan yang diberikan selanjutnya adalah praktek menggosok gigi. Setiap tim dokter yang menjadi narasumber memberikan materi secara praktek kepada semua peserta. Pada praktek pertama, guru diberikan contoh praktek menggosok gigi melalui gigi palsu. Setiap doktet memberikan penjelasan beserta praktek kepada peserta kegiatan. Selanjutnya, di hari yang lain, guru-guru diminta untuk praktek mengajar menggosok gigi dan langsung diamati oleh dokter gigi. Apabila guu mengalami kesalahan, maka dokter gigi tersebut akan memperbaiki kata-kata/ informasi tersebut.

3. Pencapaian Manfaat

Manfaat yang diharap diperoleh oleh peserta kegiatan adalah sebagai berikut:

3.1 Dapat memahami karakteristik anak berkebutuhan khusus

3.2 Dapat memahami tentang binadiri anak tunagrahita

3.3 Dapat memahami dan membuat RPP binadiri pada anak tunagrahita

3.4 Mampu melakukan praktek menggosok gigi dengan baik dan benar

\section{KESIMPULAN}

Kegiatan pengabdian kepada masyarakat yang dilaksanakan merupakan perwujudan dari Tri Dharma Perguruan Tinggi. Kegiatan yang dilaksanakan tentang program pelatihan menggosok gigi dalam meningkatkan keterampilan bina diri siswa tunagrahita di slb se-Kota Padang, difokuskan pada program pelatihan menggosok. Kegiatan ini dilaksanakan dalam bentuk pelatihan, serta praktek pembelajaran di sekolah masing-masing guru yang mengikuti kegiatan ini. Kegiatan ini diselenggarakan berdasarkan temuan di Sekolah Luar Biasa yang banyak mengalami kendala dalam mengajarkan menggosok gigi pada anak tunagrahita di Kota Padang. Berdasarkan hasil kegiatan yang telah dilakukan, terlihat bahwa kemampuan guru dalam menggosok gigi telah meningkat, hal ini diharapkan dapat membantu anak didiknya untuk dapat menggosok gigi dengan benar.

\section{DAFTAR RUJUKAN}

Ardiyanto, S. (2014). Meningkatkan Kemampuan Bina Diri Melalui Analisis Tugas pada Anak Tunagrahita Sedang Kelas 1 di SLB Limas Padang. E-JUPEKhu (Jurnal Ilmiah Pendidikan Khusus), 3(April), 17-37.

Horner, R. D., \& Keilitz, I. (2006). Training mentally retarded adolescents to brush their teeth. Journal of Applied Behavior Analysis, 8(3), 301-309. https://doi.org/10.1901/jaba.1975.8-301

Mostofsky DI, Forgione AG, Giddo DB, editors. Behavioral dentistry. New York: Blackwell Munksgaard, 2006. p. 19-26.

Pangemanan, D. H. C. (2014). Hubungan Tingkat Pengetahuan Orang Tua Dengan Kebersihan Gigi dan Mulut Anak di TK Tunas Bhakti Manado. Jurnal E-GiGi (EG), Volume 2, Nomor 2, 2, 7-10.

Pintauli S, Hamada T. Menuju gigi dan mulut sehat. Medan: USU Press, 2008: 4-8, 74-75, 79-81.

Pujiyasari, S., Hartini, S., \& Nurullita, U. (2014). Pengaruh metode latihan menggosok gigi dengan kemandirian menggosok gigi anak retardasi mental usia sekolah. Jurnal Keperawatan Dan Kebidanan, 1, 1-11. https://doi.org/10.1017/CBO9781107415324.004

Sutjipto, Chrisdwianto., dan kawan kawan. (2013). Mulut Anak Usia 10 - 12 Tahun Di Sd Kristen Eben. Gambaran Tindakan Pemeliharan Kesehatan Gigi Dan Mulut Anak Usia 10 - 12 Tahun Di Sd Kristen Eben Haezar 02 Manado, 697-706.

Widya, M. (2003). Bina Diri Bagi Anak Berkebutuhan Khusus (ABK).

Yosiani, N. (2014). Relasi Karakteristik Anak Tunagrahita Dengan Pola Tata Ruang Belajar Sekolah Luar Biasa. Jurnal, I(2), 111-124. 